\title{
Application of Maillard reaction products on chia seed oil microcapsules with different core/wall ratios
}

\author{
Claudia N. Copado a , Bernd W.K. Diehl ${ }^{\text {b }}$, Vanesa Y. Ixtaina a , Mabel C. Tomás a, * \\ a Centro de Investigación y Desarrollo en Criotecnología de Alimentos (CIDCA), CCT La Plata (CONICET), Facultad de Ciencias Exactas (FCE), Universidad \\ Nacional de La Plata (UNLP), Argentina \\ b Spectral Service GmbH Laboratorium fur Auftragsanalytik, Emil Hoffman Str. 33, D-50996 Cologne, Germany
}

\section{A R T I C L E I N F O}

\section{Article history:}

Received 8 May 2017

Received in revised form

31 July 2017

Accepted 2 August 2017

Available online 4 August 2017

\section{Keywords:}

Chia oil

Omega-3 fatty acids

Microencapsulation

Physicochemical properties

\begin{abstract}
A B S T R A C T
This research studies the physical properties of microcapsules formulated with different concentrations of chia oil, using Maillard Reaction Products (MRPs) with different protein:carbohydrate ratio as encapsulants. Microcapsules were obtained from freeze-drying of $\mathrm{O} / \mathrm{W}$ emulsions composed by nonheated/heated aqueous phases containing NaCas (10\%wt) and lactose (10 or $20 \% \mathrm{wt} / \mathrm{wt}$ ) blends. Chia oil $(10,15$ or $20 \% \mathrm{wt} / \mathrm{wt})$ constituted the oil phases. The moisture content of microcapsules was 0.31 $-2.23 \%$ d.b., while the water activity was $\sim 0.500$. The dispersibility and color were also studied. The microencapsulation efficiency varied between 41.43 and $83.95 \%$. The bulk density was $323-551 \mathrm{~kg} / \mathrm{m}^{3}$ and $244-301 \mathrm{~kg} / \mathrm{m}^{3}$ for tapped and aerated density, respectively. All microcapsules exhibited an outer topography characterized by flakes and agglomerates without cracks or dents. The particle size distribution and $\mathrm{D}[3,2]$ of reconstituted emulsions were analyzed. The heat treatment improved the protection of chia oil against lipid oxidation in most samples, partially due to the antioxidant properties of the MRPs. Also, the oil content and the protein:carbohydrate ratio affected de oxidative stability. Thus, MRPs produced by heat treatment of NaCas-lactose mixture with different protein:carbohydrate ratios were effective for conferring microencapsulated chia oil additional oxidative stability.
\end{abstract}

๑) 2017 Published by Elsevier Ltd.

\section{Introduction}

Chia (Salvia hispanica L., Labiatae) seed contains about 32-38\% of oil by weight (Ayerza \& Coates, 2005) and is a good source of polyunsaturated fatty acids (PUFAs), mainly $\omega-3$ ( $\alpha$-linolenic $\sim 60 \%$ ), with a low content of saturated fatty acids (SFAs) and bioactive compounds (Ixtaina et al., 2011).

The consumption of $\omega-3$ PUFAs offers multiple health benefits, such as protection against the incidence of coronary diseases, inflammatory disorders, asthma, retina diseases, and helping brain function. Therefore, the incorporation of these compounds in human diet is desirable (O'Dwyer, $\mathrm{O}^{\prime}$ Beirne, Ní Eidhin, $\mathrm{O}^{\prime}$ Kennedyet 2013; Kaushik, Dowling, Barrow, \& Adhikari, 2015). Health authorities of different countries have promoted the intake of foods containing high amounts of $\omega-3$ PUFAs, consequently a wide variety

\footnotetext{
* Corresponding author. Centro de Investigación y Desarrollo en Criotecnología de Alimentos (CIDCA), Universidad Nacional de La Plata (UNLP), 47 y 116 (1900) La Plata, Argentina.

E-mail address: mabtom@hotmail.com (M.C. Tomás).
}

of commercial food products enriched with this type of fatty acids has recently been developed (Jacobsen, Sørensen, \& Nielsen, 2013).

Chia oil has a high nutritional value associated with its fatty acid profile. However, its high PUFAs content makes it very susceptible to the oxidation process (Ixtaina, Nolasco, \& Tomás, 2012). Thus, microencapsulation is a technology that can be used to protect this oil against oxidation during storage and/or processing. Thus, the microcapsules obtained with chia oil could be used as an ingredient to developing $\omega-3$ fortified foods.

The main purposes of this technique are to achieve high microencapsulation efficiency and to provide high oxidative stability of the core. These two objectives are closely related to the process employed for microencapsulation, the composition of the wall material and the core/wall ratio (Gharsallaoui, Roudaut, Chambin, Voilley, \& Saurel, 2007; Sanguansri \& Augustin, 2007).

Spray-drying and freeze-drying are different processes applied for microencapsulation. Spray-drying is the most widely used process in the food industry since it is economical and flexible. Freeze-drying is a drying process carried out at low temperature, and it could be appropriate for microencapsulation of oils highly sensitive to the oxidation process, such as chia oil. Previous studies 
have shown the benefits of freeze-drying process to obtain microcapsules (Chen, Zhong, Wen, McGillivray, \& Quek, 2013; Choi et al., 2007).

The different types of wall materials provide different extents of oxidative stability, depending primarily on their ability to inhibit oxygen transfer (Kaushik et al., 2015). Proteins and carbohydrates are commonly used for microencapsulation of oils with high $\omega-3$ content (Ixtaina, Julio, Wagner, Nolasco, \& Tomás, 2015; Sanguansri \& Augustin, 2007). The proteins and carbohydrates blends are excellent for microencapsulation (Rosenberg \& Sheu, 1996). The emulsification properties of proteins and particularly sodium caseinate (NaCas), seem to offer the functional and physical characteristics necessary to encapsulate lipid core materials (Hogan, McNamee, O'Riordan, \& O'Sullivan, 2001). The disaccharide lactose forms a continuous glass phase in which the protein chains are dispersed and improve the drying properties of the wall (Rosenberg \& Sheu, 1996). Different researchers have studied the drying of $\mathrm{O} / \mathrm{W}$ emulsions using NaCas and lactose (Calvo, Hernández, Lozano, \& González-Gómez, 2010; Ixtaina et al., 2015; Velasco, Marmesat, Dobarganes, \& Márquez-Ruiz, 2006). The Maillard reaction products (MRPs), formed when proteins and carbohydrates with reducing sugar groups are mixed under certain temperature and time conditions, can be used to enhance the oxidative stability of oils with high PUFAs content. The proteincarbohydrate conjugates formed as consequence of Maillard reaction have been shown to have emulsifying and antioxidant capacity. Thus, they have been applied to microencapsulate different oils (Augustin, Sanguansri, \& Bode, 2006; Jacobsen et al., 2013; Rusli, Sanguansri, \& Augustin, 2006).

Some studies regarding the microencapsulation of chia seed oil have been published (Escalona-García et al., 2016; González, Martínez, Paredes, León, \& Ribotta, 2016; Ixtaina et al., 2015; Martínez et al., 2015; Rodea-González et al., 2012). However, none of them reported the use of MRPs as wall material to encapsulate chia oil. This research was carried out to study whether MRPs produced by heat treatment of NaCas-lactose mixture with different protein:carbohydrate and core/wall ratios would be effective for conferring microencapsulated chia oil additional oxidative stability.

The aim of this research was to investigate the effects of the MRPs, the oil concentration and the protein:carbohydrate ratio in the wall on the physicochemical characteristics and oxidative stability of chia seed oil microencapsulated using NaCas and lactose by freeze-drying for the application as functional ingredient in foods.

\section{Materials and methods}

\subsection{Materials}

Commercial chia cold-pressed oil was provided by Nutracéutica Sturla S.R.L (Argentina) and stored for 3 days at $4 \pm 1{ }^{\circ} \mathrm{C}$ without head space protected from light and oxygen.

Sodium caseinate was purchased from Sigma-Aldrich Company
(St. Louis, MO, USA), D-lactose monohydrate from Cicarelli Laboratories Reagents S.A. (San Lorenzo, Argentina). All reagents were analytical grade.

\subsection{Experimental design}

A fully factorial design $(3 \times 2 \times 2)$, with two replications, was applied to study the effects of three factors, including the MRPs -obtained by heat treatment at $60{ }^{\circ} \mathrm{C}$ for $30 \mathrm{~min}$-; the core/wall ratios; and the different concentrations of lactose. Twelve different emulsions were prepared (Table 1) and the microcapsules were produced from them as described in sections 2.3.1 and 2.3.3. The microcapsules were subjected to a storage trial during 30 days. About $15 \mathrm{~g}$ of each type of microcapsule was placed in an open Petri dish covered by foil with small holes and placed in desiccators at a relative humidity of $33 \%$ (using supersaturated solution of $\mathrm{MgCl}_{2}$ ) at room temperature.

\subsection{Methods}

\subsubsection{Emulsion preparation}

Chia oil-in-water $(\mathrm{O} / \mathrm{W})$ emulsions were composed of NaCas (10\% in weight (wt)), different lactose concentrations (10 or $20 \% \mathrm{wt} /$ wt), and 10,15 or $20 \%$ (wt/wt) of chia oil (Table 1 ).

Prior to emulsification, the NaCas was dissolved in distilled water at $50{ }^{\circ} \mathrm{C}$ using magnetic agitation. For emulsions containing lactose without heat treatment, the carbohydrate was incorporated in the aqueous phase at $25^{\circ} \mathrm{C}$. In the case of emulsions with lactose and heat treatment, the protein-carbohydrate mixture was heated at $60^{\circ} \mathrm{C}$ in a water-bath and held for $30 \mathrm{~min}$ in order to promote the MRPs (Augustin et al., 2006). Nisine $(0.0012 \mathrm{~g} / 100 \mathrm{~g})$ and potassium sorbate $(0.1 \mathrm{~g} / 100 \mathrm{~g})$ were used to prevent microbial growth.

Preliminary homogenization was performed for $1 \mathrm{~min}$ at 9500 rpm using an Ultra Turrax T-25 (IKA Labortechnik, Germany), equipped with a S25N-18G dispersing tool. The resultant preemulsions were further subjected to a second stage of homogenization in a Panda 2K high pressure valve homogenizer (GEA Niro Soavi, Parma, Italy) at 600 bar, with four recirculation cycles.

\subsubsection{Parent emulsion characterization}

2.3.2.1. Particle size distribution and mean diameter. The particle size distribution of the emulsions was determined by light scattering using a Mastersizer 2000 instrument equipped with a Hydro 2000MU as dispersion unit (Malvern Instruments Ltd., Worcestershire, UK) (Ixtaina et al., 2015). The pump speed was settled at $2000 \mathrm{rpm}$. The refractive index of the disperse phase was 1.47. The droplet size was reported as Sauter diameter (D [3, 2]), which estimates the specific surface area of the emulsions (Ixtaina et al., 2015).

The Span value was calculated according to Eq. (1):

Table 1

Formulations for chia O/W emulsions previous to freeze-drying based on $3 \times 2 \times 2$ full factorial design. Experimental parameters and samples codes.

\begin{tabular}{|c|c|c|c|}
\hline \multicolumn{2}{|l|}{10} & \multicolumn{2}{|l|}{20} \\
\hline \multicolumn{2}{|c|}{ Heat treatment } & \multicolumn{2}{|c|}{ Heat treatment } \\
\hline Without & With & Without & With \\
\hline 100C10L & 100C10LHT & $100 \mathrm{C} 20 \mathrm{~L}$ & 100C20LHT \\
\hline 15OC10L & 15OC10LHT & $150 C 20 \mathrm{~L}$ & 15OC20LHT \\
\hline 200C10L & 200C10LHT & $200 C 20 \mathrm{~L}$ & 200C20LHT \\
\hline
\end{tabular}


Span $=\frac{(d(v, 90))-(d(v, 10))}{(d(v, 50))}$

where $d(v, 10), d(v, 50)$, and $d(v, 90)$ are diameters at $10 \%, 50 \%$, and $90 \%$ cumulative volume calculated from the particle size distribution curves, respectively.

\subsubsection{Preparation of microcapsules by freeze-drying}

First, the samples were frozen. For that, the emulsions (100 g) were placed into plastic trays $(12.5 \mathrm{~cm} \times 16.0 \mathrm{~cm})$, frozen at $-20 \pm 1{ }^{\circ} \mathrm{C}$ for $48 \mathrm{~h}$ and then transferred to $-80 \pm 1^{\circ} \mathrm{C}$ for $24 \mathrm{~h}$. Following, microcapsules were obtained from the frozen emulsions by freeze-drying in laboratory scale equipment for $48 \mathrm{~h}$. The samples were ground using a manual mortar and sifted using a plastic mesh equivalent to ASTM No. 7 sieve in order to standardize the powder size.

\subsubsection{Microcapsule characterization}

2.3.4.1. Moisture content. The moisture content of the chia oil powders $(2 \mathrm{~g})$ was measured gravimetrically by drying the microcapsules ( $24 \mathrm{~h}, 70^{\circ} \mathrm{C}, 29 \mathrm{in} \mathrm{Hg}$ ) in a vacuum oven (Instrumentación Científica S.A., Buenos Aires, Argentina) (Baik et al., 2004).

2.3.4.2. Water activity. This parameter was determined using an AquaLab Water Activity Meter CX2 model Decagon Devices Inc, USA, at $25 \pm 0.5^{\circ} \mathrm{C}$.

2.3.4.3. Essential fatty acid content. The $18: 2(\omega-6)$ and 18:3 ( $\omega-3)$ content was determined by ${ }^{1} \mathrm{H}$ NMR spectroscopy. Approximately $300 \mathrm{mg}$ of each sample was weighed and dissolved in $1.5 \mathrm{~mL}$ chloroform- $\mathrm{d}_{1}$. The mixture was ultrasonicated for $30 \mathrm{~min}$ and afterwards was shaken for $2 \mathrm{~h}$. Then the mixture was centrifuged and $2 \mathrm{~mL}$ of dimethylsulfoxide- $\mathrm{d}_{6}$ with tetramethylsilane (TMS) was added to the mixture.

A Bruker Avance III $500 \mathrm{MHz}$ spectrometer (Bruker Biospin, Rheinstetten, Germany) with a BBFOPLUS SmartProbe probe equipped with a Bruker Automatic Sample Changer (B-ACS 120) was used to carry out the NMR measurements at ambient temperature. ${ }^{1} \mathrm{H}$ NMR spectra were recorded using a standard 1D pulse sequence (PS) at a $30^{\circ}$ flip angle with 512 scans, $131 \mathrm{k}$ time domain, $24.02 \mathrm{ppm}$ spectral width, receiver gain of 90.5 , and $5.45 \mathrm{~s}$ acquisition time. The data were recorded automatically by ICON-NMR (Bruker Biospin, Rheinstetten, Germany). All NMR spectra were manually phased, baseline-corrected and integrated by a Topspin 3.2 (Bruker Biospin, Rheinstetten, Germany).

Specific NMR regions were used for quantification: $\delta$ 2.75-2.85 ppm (18:3) and $\delta$ 2.69-2.75 ppm (18:2).

2.3.4.4. Microencapsulation efficiency of total oil, $\omega-6$ and $\omega-3$ PUFAs. Microencapsulation efficiency of total oil (ME\%) was performed according to Augustin, Bhail, Shen, Oiseth, and Sanguansri (2015) with some modifications. About $1 \mathrm{~g}$ of microcapsules was placed on filter paper (Whatman $\mathrm{N}^{\circ} 4$ ), washed three times with $10 \mathrm{~mL}$ of hexane, collected on a flask and then evaporated under a nitrogen stream. The free oil content was determined by weight difference. It was assumed that the total oil was equal to the initial oil since previous study (Ixtaina et al., 2015) showed that all the initial chia oil remained in the microcapsules. Microencapsulation efficiency was calculated according to Eq (2):

$\mathrm{ME} \%=\left(\frac{\text { Total Oil }- \text { Free Oil }}{\text { Total Oil }}\right) \times 100$

Microencapsulation efficiency of $\omega-6\left(\mathrm{ME}_{\omega-6}\right)$ and $\omega-3(\mathrm{ME} \% \omega-$
3) PUFAs were calculated by the data from the fatty acid analysis of encapsulated oil and total oil determined by ${ }^{1} \mathrm{H}$ NMR spectroscopy according to Eqs. (3) and (4):

$$
\begin{aligned}
& \mathrm{ME} \%_{\omega-6}=\frac{\omega-6 \text { of microencapsulated oil }}{\omega-6 \text { of total oil }} \\
& \mathrm{ME}_{\omega-3}=\frac{\omega-3 \text { of microencapsulated oil }}{\omega-3 \text { of total oil }}
\end{aligned}
$$

2.3.4.5. Powder bulk density and compressibility. In addition to the ME of microcapsules, other quality control parameters such as bulk density, Carr Index and Hausner Ratio are used to evaluate the powder flRatio are (Fitzpatrick, 2005). The bulk density can be defined as the mass of a powder divided by the volume occupied by it. The bulk density can be classified as aerated and tapped densities. The aerated bulk density $\left(\rho_{A}\right)$ was analyzed by allowing the dispersed powder to settle in a container due to the gravity influence, whereas the tapped bulk density $\left(\rho_{\mathrm{T}}\right)$ was obtained by tapping the container holding the powder. These densities were measured according to Holgado, Márquez-Ruiz, Dobarganes, \& Velasco, 2013. For this propose a graduate cylinder $(100 \mathrm{~mL})$ with $25 \mathrm{~g}$ of powder was used, and the respective densities were calculated according to Eqs. (5) and (6).

$\rho_{A}=m_{0} / v_{0}$

where $v_{0}$ : volume occupied by the powder $\left(\mathrm{m}^{3}\right), \mathrm{m}_{0}$ : powder mass $(\mathrm{kg})$.

$\rho_{T}=m_{0} / v_{T}$

wher $\mathrm{v}_{\mathrm{T}}$ : volume occupied by the powder after tapping $\left(\mathrm{m}^{3}\right)$.

From the parameters previously described, the compressibility (C) was calculated according to Eq (7):

$C=\left(\rho_{T}-\rho_{A}\right) / \rho_{T}$

2.3.4.6. Microstructure. The microcapsule morphology was study by scanning electron microscopy (SEM). The microcapsules were fixed on a sample holder with graphite tape, and then metalized with gold (SPI Supplies) Sputter. The samples were observed using a FEI-Quanta 200 instrument in high vacuum mode operating at 20 $\mathrm{Kv}$.

2.3.4.7. Color. Samples were homogeneously distributed in a glass Petri dish (diameter $95 \mathrm{~mm}$ ) and the color of the microcapsule surface was measured using a Minolta colorimeter (CR-400, Konica Minolta Sensing Inc., Japan) calibrated with a white standard tile. Color was recorded using the $L^{*}$ (lightness) $a^{*}$ (red-green component) and $b^{*}$ (yellow-blue component) values of samples.

2.3.4.8. Particle size distribution and mean diameter of the reconstituted emulsion. The dispersion of the powder (solid content $10 \%$ $\mathrm{wt} / \mathrm{wt}$ ) was made by stirring the microcapsules in water at room temperature for $30 \mathrm{~min}$. The measurements were carried out according to section 2.3.2.1.

2.3.4.9. Dispersibility. Dispersibility of the microcapsules was determined according to Klinkesorn, Sophanodora, Chinachoti, McClements, and Decker (2005). Samples $\sim 0.3 \mathrm{mg}$ of powder $/ \mathrm{mL}$ 
of distilled water were added within the stirring chamber $(500 \mathrm{~mL})$ of a laser diffraction instrument (Malvern Mastersizer Model 2000 E, Malvern Instruments, Worcestershire, UK) spinning at $2000 \mathrm{rpm}$, measuring changes in mean particle diameter (D [3,2]) and obscuration during $5 \mathrm{~min}$.

2.3.4.10. Oxidative stability. An accelerated oxidation test of the bulk oil and the microcapsules was performed in a Rancimat (Metrohm 679, Switzerland) (AOCS Cd 12b-92, 2013) apparatus using $3.0 \mathrm{~g}$ of oil or $1.5 \mathrm{~g}$ of microcapsules at $98{ }^{\circ} \mathrm{C}$ with continuous bubbling of an air stream at $20 \mathrm{~L} / \mathrm{h}$. Stability was expressed as induction time $\left(\mathrm{t}_{\mathrm{i}}\right)$, in hours.

2.3.4.11. Peroxide value. Peroxide value was evaluated spectrophotometrically according to the method of Diaz, Dunn, MCClements, and Decker (2003). Briefly, the emulsions were reconstituted from the powders according to 2.3.4.7 section. The extraction of lipid hydroperoxides was made by mixing $300 \mu \mathrm{L}$ of the reconstituted emulsion with $1.5 \mathrm{~mL}$ of an iso-octane/ isopropanol (3:1 v:v) mixture, vortexing 3 times for $10 \mathrm{~s}$ each. The phases were separated by centrifuging and the organic phase was used for analysis. The organic phase was added to $2.8 \mathrm{~mL}$ of a methano/butanol solution $(2: 1 \mathrm{v} / \mathrm{v})$ followed by $15 \mu \mathrm{L}$ of $3.94 \mathrm{M}$ thiocyanate solution and $15 \mu \mathrm{L}$ of $0.072 \mathrm{M}$ acidic ferrous iron solution. After $20 \mathrm{~min}$ in the dark at room temperature, the absorbance was measured at $510 \mathrm{~nm}$. Lipid hydroperoxide concentrations were determined using cumene hydroperoxide standard curve.

\subsubsection{Statistical analysis}

Multifactorial ANOVA test was used to analyze the main effects of each factor and the interactions between them. Tukey's High Meaningful Difference test was performed ( $p \leq 0.05$ ) for mean multiple comparisons. Statgraphics Centurion software (Version XV. II for Windows, Manugistics Inc., USA) was used for the statistical analysis.

\section{Results and discussion}

\subsection{Parent emulsion characterization}

\subsubsection{Particle size distribution and mean diameter}

It is important to obtain emulsions with high physical stability due to the relatively long time required for freeze drying, during which possible losses of the material to be encapsulated could occur (Chen et al., 2013). In this sense, the particle size distribution and the mean diameter are relevant because these parameters are closely related to the physical stability of the emulsions.

Fig. 1 shows the particle size distribution curves for the parent emulsions prepared with different protein:carbohydrate ratios and oil concentrations. The particle diameters ranged from 0.1 to 10 and 0.1-239 $\mu \mathrm{m}$ for emulsions with and without heat treatment, respectively. The particle size distribution profiles of the parent emulsions were bimodal, except for sample with $15 \%$ of chia oil, $20 \%$ of lactose without heat treatment which presented unimodal distribution. In the case of emulsions with a similar protein:carbohydrate ratio and the application of heat treatment, the particle size distribution was narrower than the other ones (Fig. 1). It can also be seen that the Span values of emulsions without heat treatment (1.1770-4.0900) were higher than those with thermal treatment (1.0260-2.5685), showing a lower polidispersibility level in these last systems. A similar result was obtained by Zhang
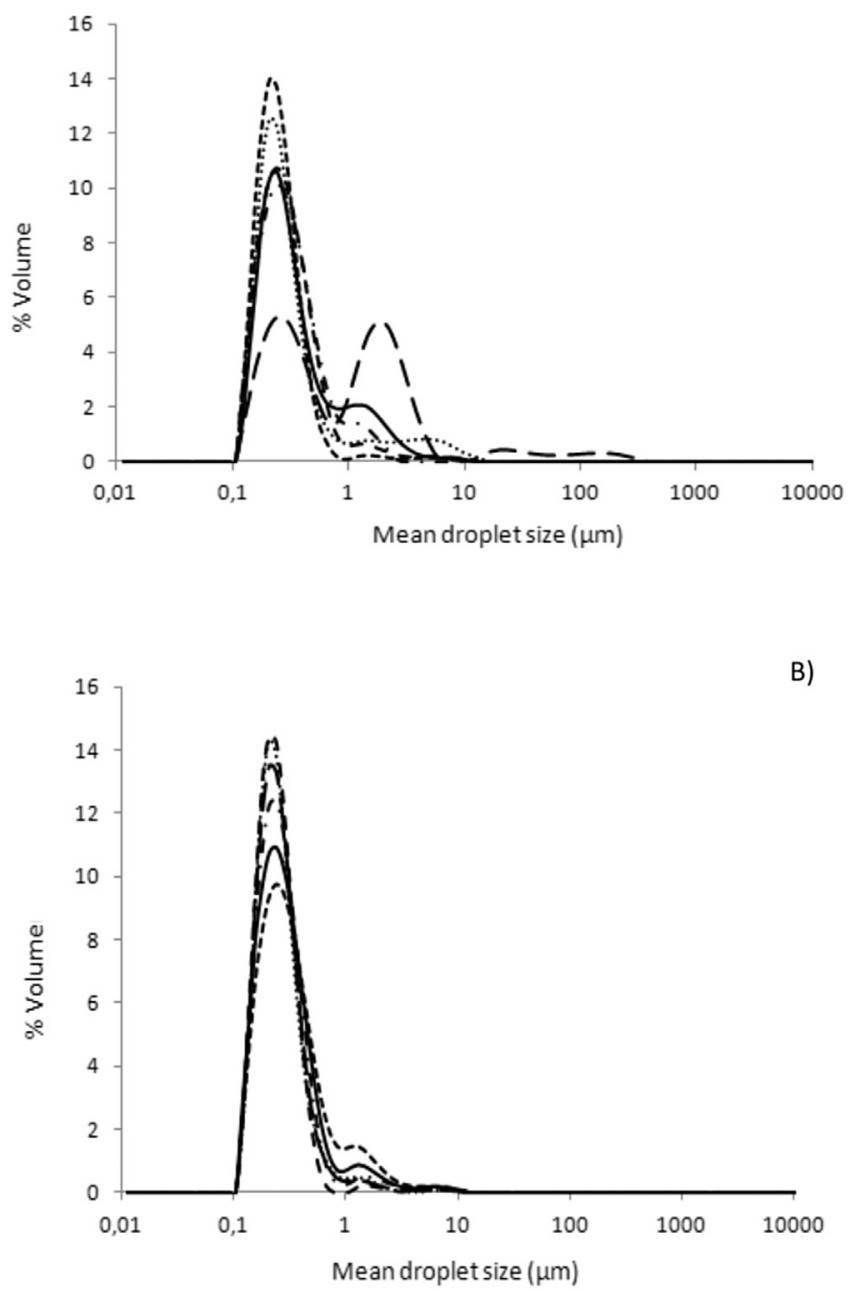

Fig. 1. Particle size distribution (\% volume) of parent emulsions: A) without heat treatment B) with heat treatment - . . . 100C10L; — 150C10L; - $-200 \mathrm{C} 10 \mathrm{~L}$; - - - 100C20L; -.-.-- 150C20L; .......... 200C20L.

et al. (2015), who observed that the emulsion with MRPs showed the smallest particle size and the narrowest size distribution. This behavior can be explained by the excellent emulsifying property of the protein-polysaccharide conjugates (Akhtar \& Dickinson, 2007).

\subsection{Microcapsule characterization}

\subsubsection{Moisture content (MC)}

Table 2 shows that lactose concentration and heat treatment presented a very significant effect $(p \leq 0.001)$ on moisture content. Also, double and triple significant interactions were found between factors, except lactose concentration $\mathrm{x}$ heat treatment.

The obtained values ranged between 0.31 and $2.23 \%$ d.b. (Table 3), which are lower than those required to achieve chia oil microcapsules with a good stability during storage (3-4\% d.b.) (Klaypradit \& Huang, 2008).

\subsubsection{Water activity $\left(a_{w}\right)$}

There were no significant effects ( $p>0.05$ ) of oil load, lactose concentration or heat treatment on $\mathrm{a}_{\mathrm{w}}$ (Tables 3 and 4 ). All samples 
Table 2

Multifactorial analysis of variance (ANOVA) for the physicochemical properties of microcapsules of chia seed oil.

\begin{tabular}{|c|c|c|c|c|c|c|c|c|c|c|c|c|}
\hline \multirow[t]{3}{*}{ Main effects } & \multirow[t]{3}{*}{ D.F. } & \multicolumn{11}{|c|}{ Sum of squares } \\
\hline & & \multirow[t]{2}{*}{ MC } & \multirow[t]{2}{*}{$a_{w}$} & \multirow[t]{2}{*}{ ME } & \multirow[t]{2}{*}{$\mathrm{ME}_{\omega-6}$} & \multirow[t]{2}{*}{$\mathrm{ME}_{\omega-3}$} & \multirow[t]{2}{*}{$\rho \mathrm{a}$} & \multirow[t]{2}{*}{$\rho_{\mathrm{e}}$} & \multirow[t]{2}{*}{ C } & \multirow[t]{2}{*}{$\mathrm{D}[3,2]$} & \multicolumn{2}{|c|}{ Oxidative stability } \\
\hline & & & & & & & & & & & Initial & Final \\
\hline Oil load $(A)$ & 2 & 0.036 & 0.000 & $737.95^{*}$ & $1083.15^{* * *}$ & $591.53^{* * *}$ & 1027.0 & 23172.3 & 0.011 & $195.168^{* * *}$ & $567.496^{* * *}$ & 331.704 \\
\hline Lactose concentration (B) & 1 & $0.814^{* * *}$ & 0.002 & $424.89^{*}$ & $512.24^{* * *}$ & $499.14^{* * *}$ & 693.4 & 13254.0 & 0.000 & $30.736^{* *}$ & $480.078^{* * *}$ & 158.569 \\
\hline Heat treatment $(\mathrm{C})$ & 1 & $1.591^{* * *}$ & 0.000 & $705.94^{* *}$ & $616.61^{* * *}$ & $623.32^{* * *}$ & 126.0 & 2604.2 & 0.009 & $58.101^{* * *}$ & $108.120^{*}$ & 78.156 \\
\hline $\mathrm{AxB}$ & 2 & $1.205^{* * *}$ & 0.000 & 224.57 & $165.92^{* * *}$ & $112.08^{* *}$ & 1348.0 & 13456.0 & 0.011 & $65.433^{* *}$ & $1618.640^{* * *}$ & 729.329* \\
\hline $\mathrm{AxC}$ & 2 & $0.700^{* *}$ & 0.000 & 90.12 & $105.03^{* *}$ & 45.23 & 89.3 & 25106.3 & $0.047^{* *}$ & $115.943^{* * *}$ & $242.242^{* *}$ & 40.815 \\
\hline $\mathrm{BxC}$ & 1 & 0.028 & 0.000 & $583.00^{* *}$ & $513.84^{* * *}$ & $702.11^{* * *}$ & 287.0 & 5340.2 & 0.004 & 13.599 & 8.378 & 62.823 \\
\hline $\mathrm{AxBxC}$ & 2 & $2.792^{* * * *}$ & 0.002 & 454.96 & $347.21^{* * *}$ & $546.73^{* * *}$ & 2093.3 & 11825.3 & 0.006 & $28.000^{*}$ & $579.124^{* * * *}$ & 48.160 \\
\hline Pure error & 12 & 0.420 & 0.007 & 822.26 & 68.95 & 91.77 & 11583.5 & 43141.0 & 0.041 & 41.574 & 189.681 & 1049.950 \\
\hline Total & 23 & 7.588 & 0.011 & 4043.70 & 3413.26 & 3211.91 & 17246.6 & 137899.0 & 0.130 & 548.554 & 3793.760 & 2499.510 \\
\hline
\end{tabular}

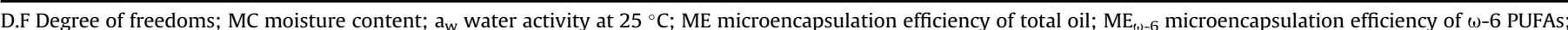

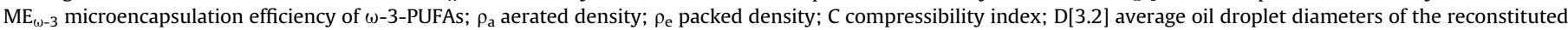
emulsions ${ }^{*} \mathrm{p} \leq 0.05$. $^{* *} \mathrm{p} \leq 0.01{ }^{* * *} \mathrm{p} \leq 0.001$.

Table 3

Physicochemical properties of microcapsules of chia seed oil at initial time $(t=0 \mathrm{~d})$.

\begin{tabular}{|c|c|c|c|c|c|c|c|}
\hline Sample & $\begin{array}{l}\text { Moisture content } \\
\text { (\%, d.b.) }\end{array}$ & $\mathrm{a}_{\mathrm{w}\left(25^{\circ} \mathrm{C}\right)}$ & $\begin{array}{l}\text { Oxidative stability } \\
\left(t_{i}, h\right)\end{array}$ & $\begin{array}{l}\text { Aerated bulk } \\
\text { density }\left(\mathrm{kg} / \mathrm{m}^{3}\right)\end{array}$ & $\begin{array}{l}\text { Tapped bulk } \\
\text { density }\left(\mathrm{kg} / \mathrm{m}^{3}\right)\end{array}$ & $\begin{array}{l}\text { Compressibility } \\
\text { Index }\end{array}$ & $\begin{array}{l}\text { Particle size of the reconstituted } \\
\text { emulsion } \mathrm{D}[3,2](\mu \mathrm{m})\end{array}$ \\
\hline 100C10L & $1.34^{\mathrm{bcd}}$ & $0.515^{\mathrm{a}}$ & $11.91^{\mathrm{ab}}$ & $301^{a}$ & $551^{a}$ & $0.435^{\mathrm{b}}$ & $0.283^{\mathrm{a}}$ \\
\hline $150 C 10 \mathrm{~L}$ & $0.73^{\mathrm{abc}}$ & $0.483^{\mathrm{a}}$ & $21.31^{\text {cde }}$ & $266^{a}$ & $340^{\mathrm{a}}$ & $0.217^{\mathrm{a}}$ & $0.450^{\mathrm{ab}}$ \\
\hline $200 C 10 \mathrm{~L}$ & $1.02^{\mathrm{abc}}$ & $0.495^{\mathrm{a}}$ & $15.23^{\mathrm{abc}}$ & $244^{a}$ & $323^{a}$ & $0.244^{\mathrm{a}}$ & $0.957^{\mathrm{ab}}$ \\
\hline $100 C 20 \mathrm{~L}$ & $0.77^{\mathrm{abc}}$ & $0.500^{\mathrm{a}}$ & $25.13^{\text {de }}$ & $266^{a}$ & $450^{\mathrm{a}}$ & $0.322^{\mathrm{ab}}$ & $0.266^{\mathrm{a}}$ \\
\hline $150 C 20 \mathrm{~L}$ & $0.69^{\mathrm{ab}}$ & $0.520^{\mathrm{a}}$ & $34.87^{\mathrm{f}}$ & $270^{a}$ & $402^{\mathrm{a}}$ & $0.265^{\mathrm{a}}$ & $0.280^{\mathrm{a}}$ \\
\hline $200 C 20 \mathrm{~L}$ & $0.31^{\mathrm{a}}$ & $0.508^{a}$ & $11.74^{\mathrm{ab}}$ & $286^{a}$ & $414^{\mathrm{a}}$ & $0.230^{\mathrm{a}}$ & $16.778^{c}$ \\
\hline 100C10LHT & $1.44^{\mathrm{cd}}$ & $0.481^{\mathrm{a}}$ & $9.62^{\mathrm{a}}$ & $260^{\mathrm{a}}$ & $351^{a}$ & $0.217^{\mathrm{a}}$ & $0.292^{\mathrm{a}}$ \\
\hline 150C10LHT & $2.23^{\mathrm{e}}$ & $0.488^{\mathrm{a}}$ & $20.29^{\mathrm{bcd}}$ & $261^{a}$ & $359^{a}$ & $0.249^{\mathrm{a}}$ & $0.390^{\mathrm{a}}$ \\
\hline 200C10LHT & $0.76^{\mathrm{abc}}$ & $0.496^{\mathrm{a}}$ & $27.73^{\text {def }}$ & $255^{\mathrm{a}}$ & $352^{a}$ & $0.232^{\mathrm{a}}$ & $0.516^{\mathrm{ab}}$ \\
\hline 100C20LHT & $0.74^{a b c}$ & $0.522^{\mathrm{a}}$ & $51.96^{\mathrm{g}}$ & $290^{\mathrm{a}}$ & $430^{a}$ & $0.212^{\mathrm{a}}$ & $0.292^{\mathrm{a}}$ \\
\hline 150C20LHT & $0.80^{a b c}$ & $0.497^{\mathrm{a}}$ & $29.33^{\mathrm{ef}}$ & $263^{a}$ & $391^{a}$ & $0.264^{\mathrm{a}}$ & $0.291^{\mathrm{a}}$ \\
\hline 200C20LHT & $1.99^{\mathrm{de}}$ & $0.513^{\mathrm{a}}$ & $6.73^{\mathrm{a}}$ & $276^{a}$ & $471^{a}$ & $0.306^{\mathrm{a}}$ & $2.889^{\mathrm{b}}$ \\
\hline
\end{tabular}

$\mathrm{a}_{\mathrm{w}}$ water activity at $25^{\circ} \mathrm{C} ; \mathrm{t}_{\mathrm{i}}$, induction time.

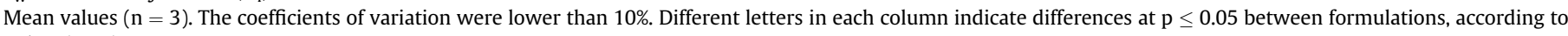
Tukey (HSD) test.

Table 4

Microencapsuation efficiency of total oil, $\omega-6$ and $\omega-3$ PUFAs of microcapsules of chia seed oil.

\begin{tabular}{|c|c|c|c|}
\hline Samples & $\begin{array}{l}\mathrm{ME} \\
(\%)\end{array}$ & $\begin{array}{l}\mathrm{ME}_{\omega-6} \\
(\%)\end{array}$ & $\begin{array}{l}\mathrm{ME}_{\omega-3} \\
(\%)\end{array}$ \\
\hline $100 C 10 L$ & $83.9^{\mathrm{b}}$ & $91.6^{f}$ & $81.4^{\mathrm{f}}$ \\
\hline $150 C 10 \mathrm{~L}$ & $74.7^{\mathrm{b}}$ & $81.2^{\mathrm{de}}$ & $78.4^{\mathrm{ef}}$ \\
\hline $200 C 10 \mathrm{~L}$ & $57.4^{\mathrm{ab}}$ & $64.3^{\mathrm{b}}$ & $58.4^{\mathrm{bc}}$ \\
\hline $100 C 20 \mathrm{~L}$ & $73.3^{\mathrm{ab}}$ & $79.9^{\text {de }}$ & $74.3^{\text {ef }}$ \\
\hline $150 C 20 \mathrm{~L}$ & $67.4^{\mathrm{ab}}$ & $75.0^{\mathrm{cd}}$ & $69.6^{\text {de }}$ \\
\hline $200 C 20 \mathrm{~L}$ & $79.7^{\mathrm{b}}$ & $82.2^{\mathrm{def}}$ & $79.6^{\mathrm{ef}}$ \\
\hline 100C10LHT & $77.2^{\mathrm{b}}$ & $86.0^{\mathrm{ef}}$ & $77.4^{\mathrm{ef}}$ \\
\hline 15OC10LHT & $72.6^{\mathrm{ab}}$ & $80.2^{\text {de }}$ & $74.0^{\mathrm{def}}$ \\
\hline 200C10LHT & $63.8^{\mathrm{ab}}$ & $68.2^{\mathrm{bc}}$ & $68.8^{\mathrm{cde}}$ \\
\hline 100C20LHT & $61.7^{\mathrm{ab}}$ & $69.1^{\mathrm{bc}}$ & $63.1^{\mathrm{bcc}}$ \\
\hline 150C20LHT & $55.4^{\mathrm{ab}}$ & $63.5^{\mathrm{b}}$ & $56.0^{\mathrm{b}}$ \\
\hline 200C20LHT & $41.4^{\mathrm{a}}$ & $46.4^{\mathrm{a}}$ & $41.3^{\mathrm{a}}$ \\
\hline
\end{tabular}

ME\% microencapsulation efficiency of total oil; ME\% ${ }_{(\omega-6}$ microencapsulation efficiency of $\omega-6$ PUFAs; ME\% $\omega_{\omega-3}$ microencapsulation efficiency of $\omega$-3-PUFAs.

Mean values $(n=3)$. The coefficients of variation were lower than $10 \%$. Different letters in each column indicate differences at $\mathrm{p} \leq 0.05$ between formulations, according to Tukey (HSD) test.

showed values $\sim 0.500$, which were lower than 0.6 considered as the upper limit for a food to be microbiologically stable (Fazaeli, Emam-Djomeh, Kalbasi Ashtari, \& Omid, 2012; Goyal et al., 2015). These values were higher than those reported by Ixtaina et al. (2015) for the microcapsules obtained by spray drying. Both $a_{w}$ level and the moisture content of microcapsules obtained in this study would be appropriate for their incorporation in dehydrated food matrices.

3.2.3. Microencapsulation efficiency of total oil (ME\%), essential fatty acid content and microencapsulation efficiency of $\omega-6(M E \% \omega-$ 6) and $\omega-3\left(M E \% \omega_{\omega-3}\right)$ PUFAs

The ME\% ranged between 41.4 and $83.9 \%$ (Table 4), which were lower than those reported by Ixtaina et al. (2015) ( 95.0\%) for microencapsulation of chia seed oil by spray-drying with NaCas and lactose. A lower ME\% for the freeze-drying process in comparison with spray-drying was also found by Chen et al. (2013), who reported that this phenomenon could be produced by the dehydration of emulsifiers during the freezing of water phase, which promotes particle-particle interactions in emulsion and reduces the emulsion stability. Thus, the encapsulated materials could be released from the core when ice crystals are removed during the drying stage.

The statistical analysis showed that the heat treatment was the most relevant factor with a negative impact, reducing the corresponding efficiency of the different microcapsules. A lesser influence was associated with the oil content and lactose concentration (Table 2). In this sense, a negative correlation was found between the total solid content and $\mathrm{ME}(\mathrm{r}=-0.52 ; \mathrm{p}=0.0090)$ and between oil content and $\mathrm{ME}(\mathrm{r}=-0.43 ; \mathrm{p}=0.0374)$. These results show the importance of having sufficient quantities of wall material for encapsulating chia oil. A significant interaction $(\mathrm{p} \leq 0.01)$ between lactose concentration and heat treatment was found. Thus, for 
samples without heat treatment, no significant differences ( $p>0.05$ ) were detected for ME\% between both of the lactose concentrations studied. However, in the case of samples with heat treatment, an increment in lactose concentration caused a decrease in $\mathrm{ME} \%$.

The essential fatty acid content of microencapsulated chia oil was 20.6-22.9 $\mathrm{g} \omega-6 / 100 \mathrm{~g}$ of oil and 58.2-65.9 $\mathrm{g} \omega-3 / 100 \mathrm{~g}$ of oil. These values were similar to those of bulk chia oil $(\omega-6=23.4 \mathrm{~g} /$ $100 \mathrm{~g} ; \omega-3=60.0 \mathrm{~g} / 100 \mathrm{~g})$, showing that microencapsulation process did not affect the essential fatty acid composition of chia oil. Thus, microcapsules could be used to fortified foods with this type of fatty acids.

Values of ME of $\omega-6$ and $\omega-3$ PUFAs calculated from the ${ }^{1} \mathrm{H}$ NMR spectroscopy data presented a high correlation with those of ME of total oil obtained by the gravimetric analysis $(r=0.97 ; p=0.0000)$. Thus, the highest ME of total oil, $\omega-6$ and $\omega-3$ PUFAs were found in non-heated samples with $10 \%$ of lactose and $10 \%$ of oil, while the lowest ones were recorded in heated samples with $20 \%$ of oil and
$20 \%$ of lactose.

\subsubsection{Bulk density}

Regarding bulk density no effects $(p>0.05)$ of the different factors investigated in the experimental design were recorded (Table 2). Bulk density varied between 323 and $551 \mathrm{~kg} / \mathrm{m}^{3}$ and 244-301 $\mathrm{kg} / \mathrm{m}^{3}$ for tapped and aerated density, respectively (Table 3). These parameters depend on the particle size, distribution and characteristics of the material. Similar values were obtained for Quispe-Condori, Saldaña, and Temelli (2011) for microcapsules with flax oil obtained by freeze drying.

The compressibility in many powders is a measure of internal cohesion, flowability, and to some extent, deformability. A low compressibility indicates a less cohesive powder and a higher bulk density (Onwulata, Konstance, \& Holsinger, 1996).

This property did not present significant differences $(p>0.05)$ between the experimental factors studied, but a significant oil load $\mathrm{x}$ heat treatment interaction $(\mathrm{p} \leq 0.01)$ was recorded. This fact is
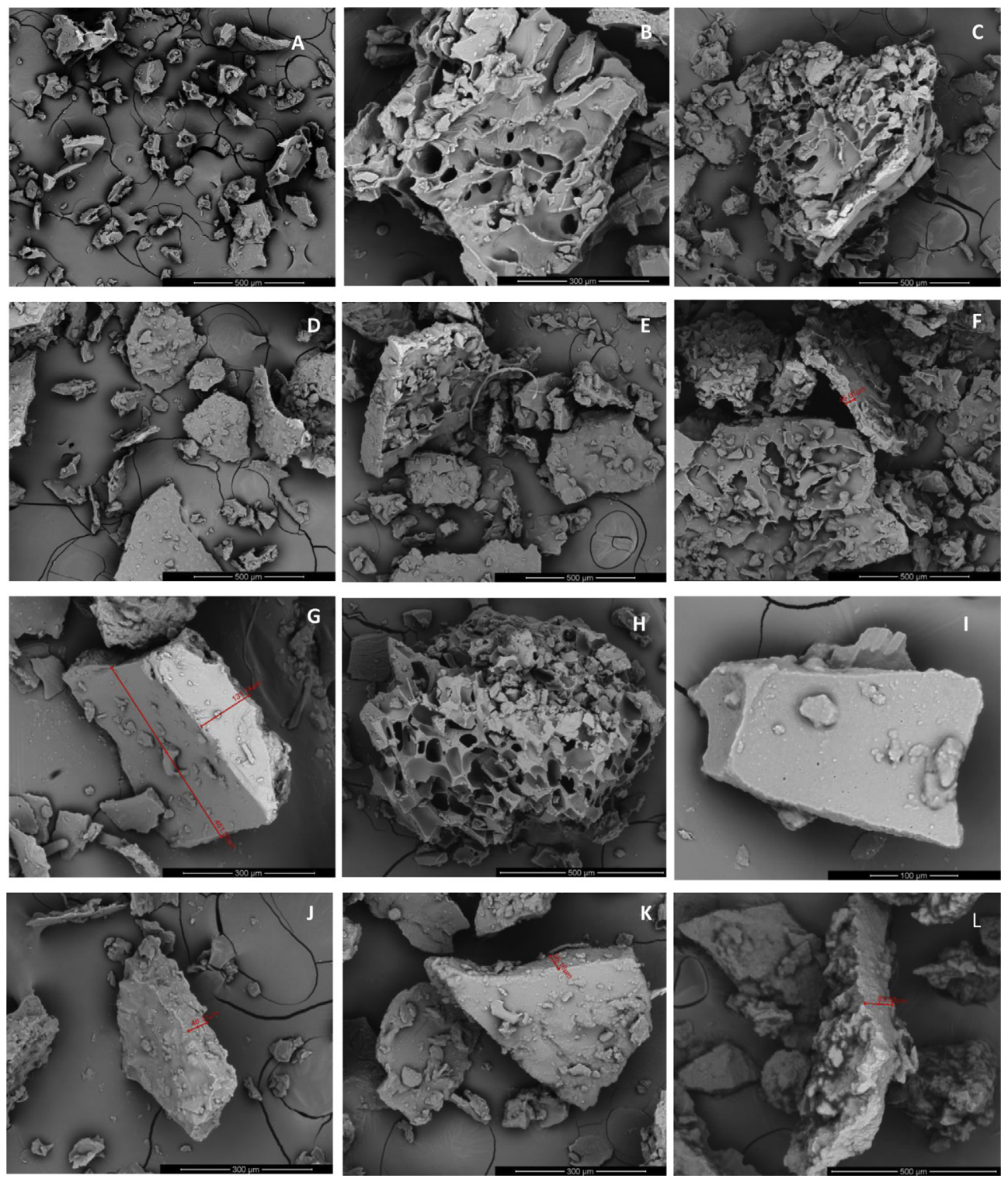

Fig. 2. Micrographs of chia oil microcapsules for different formulations: A) 100C10L, B) 150C10L, C) 200C10L, D) 100C20L, E) 150C20L, F) 200C20L, G) 100C10LHT, H) 150C10LHT, I) 200C10LHT, J) 100C20LHT, K) 150C20LHT, L) 200C20LHT. 
Table 5

Color of microcapsules of chia seed oil for different formulations during storage at $20 \pm 1{ }^{\circ} \mathrm{C}$.

\begin{tabular}{|c|c|c|c|c|c|c|}
\hline \multirow[t]{2}{*}{ Samples } & \multicolumn{3}{|l|}{$\mathrm{t}=0 \mathrm{~d}$} & \multicolumn{3}{|l|}{$\mathrm{t}=30 \mathrm{~d}$} \\
\hline & $\mathrm{L}^{*}$ & $a^{*}$ & $\mathrm{~b}^{*}$ & $\mathrm{~L}^{*}$ & $a^{*}$ & $b^{*}$ \\
\hline $100 C 10 \mathrm{~L}$ & $93.51 \pm 1.89^{\mathrm{a}}$ & $-1.01 \pm 0.18^{\mathrm{cd}}$ & $12.81 \pm 0.89^{a}$ & $91.32 \pm 0.78^{a}$ & $-1.37 \pm 0.00^{\mathrm{a}}$ & $17.84 \pm 3.00^{a}$ \\
\hline 150C10L & $92.21 \pm 0.27^{\mathrm{a}}$ & $-1.22 \pm 0.21^{\mathrm{bc}}$ & $14.06 \pm 0.16^{\mathrm{a}}$ & $94.68 \pm 5.27^{a}$ & $-1.71 \pm 0.29^{a}$ & $16.79 \pm 1.12 a$ \\
\hline $200 C 10 \mathrm{~L}$ & $92.89 \pm 2.11^{\mathrm{a}}$ & $-1.68 \pm 0.04^{\mathrm{ab}}$ & $14.34 \pm 0.34^{\mathrm{a}}$ & $90.15 \pm 1.78^{a}$ & $-2.22 \pm 0.04^{\mathrm{a}}$ & $15.59 \pm 0.29 a$ \\
\hline $100 \mathrm{C} 20 \mathrm{~L}$ & $91.94 \pm 0.44^{\mathrm{a}}$ & $-1.04 \pm 0.08^{\mathrm{cd}}$ & $13.58 \pm 0.28^{\mathrm{a}}$ & $89.71 \pm 1.77^{\mathrm{a}}$ & $-1.66 \pm 0.24^{\mathrm{a}}$ & $16.38 \pm 0.19 a$ \\
\hline $150 C 20 \mathrm{~L}$ & $91.49 \pm 0.07^{\mathrm{a}}$ & $-0.96 \pm 0.10^{\mathrm{cd}}$ & $14.29 \pm 0.34^{\mathrm{a}}$ & $90.61 \pm 1.05^{a}$ & $-1.58 \pm 0.16^{\mathrm{a}}$ & $15.87 \pm 1.11 a$ \\
\hline $200 C 20 \mathrm{~L}$ & $92.70 \pm 1.24^{\mathrm{a}}$ & $-1.83 \pm 0.01^{\mathrm{a}}$ & $15.04 \pm 0.05^{\mathrm{ab}}$ & $89.26 \pm 3.37^{a}$ & $-2.41 \pm 0.00^{\mathrm{a}}$ & $17.92 \pm 0.00 a$ \\
\hline 100C10LHT & $91.57 \pm 0.38^{\mathrm{a}}$ & $-1.01 \pm 0.18^{\mathrm{cd}}$ & $15.05 \pm 1.43^{\mathrm{ab}}$ & $88.67 \pm 1.34^{\mathrm{a}}$ & $-1.50 \pm 0.08^{\mathrm{a}}$ & $15.48 \pm 0.00 a$ \\
\hline 15OC10LHT & $93.42 \pm 1.58^{\mathrm{a}}$ & $-0.98 \pm 0.0^{\mathrm{cd}}$ & $14.02 \pm 1.27^{\mathrm{a}}$ & $91.35 \pm 0.47^{\mathrm{a}}$ & $-1.59 \pm 0.24^{\mathrm{a}}$ & $19.89 \pm 3.75 a$ \\
\hline 200C10LHT & $92.06 \pm 0.43^{a}$ & $-1.17 \pm 0.17^{\mathrm{bc}}$ & $14.775 \pm 0.05^{\mathrm{a}}$ & $89.85 \pm 0.66^{a}$ & $-1.62 \pm 0.09^{\mathrm{a}}$ & $16.35 \pm 0.34 a$ \\
\hline 100C20LHT & $91.47 \pm 0.81^{\mathrm{a}}$ & $-0.54 \pm 0.09^{d}$ & $13.625 \pm 0.35^{\mathrm{a}}$ & $89.95 \pm 0.89^{a}$ & $-0.89 \pm 0.14^{\mathrm{a}}$ & $15.70 \pm 0.65 a$ \\
\hline 15OC20LHT & $92.85 \pm 1.63^{\mathrm{a}}$ & $-0.53 \pm 0.03^{\mathrm{d}}$ & $13.57 \pm 1.00^{\mathrm{a}}$ & $91.31 \pm 2.55^{\mathrm{a}}$ & $-0.85 \pm 0.01^{\mathrm{a}}$ & $14.54 \pm 0.55 a$ \\
\hline 200C20LHT & $90.00 \pm 0.38^{\mathrm{a}}$ & $-1.27 \pm 0.23^{b c}$ & $17.64 \pm 0.21^{\mathrm{b}}$ & $88.14 \pm 2.52^{\mathrm{a}}$ & $-1.81 \pm 0.03^{\mathrm{a}}$ & $18.47 \pm 0.20 a$ \\
\hline
\end{tabular}

Different letters in each column indicate differences at $\mathrm{p} \leq 0.05$ between formulations. According to Tukey (HSD) test.

important for the homogeneous character and reproducibility of the microcapsules to be subsequently included in food products (Table 2).

\subsubsection{Microstructure}

The scanning electronic micrographs (SEM) are shown in Fig. 2. All the formulations exhibited an outer topography characterized by forming flakes and agglomerates with rough appearance without cracks or dents. The pores observed in cases $150 \mathrm{C} 10 \mathrm{~L}$, 15OC10LHT and 200C10L were possibly formed by the cavities generated by the crystals of ice or bubbles of air retained during freezing. The existence of these pores would not affect the microencapsulation efficiency. Similar results were obtained by Gan, Cheng, and Easa (2008), who worked with microencapsulated fish oil.

SEM micrographs of the microcapsules indicated that as the core:wall ratio increased, the flake size became larger and thicker.

\subsubsection{Color}

The color of the microcapsules is an important parameter because their incorporation as an ingredient in food products should not significantly alter the characteristics of the product.

The obtained results showed high $L^{*}$ values (white and luminous), which decreased with storage (except for 150C10L). Regarding $a^{*}$ values, this parameters decreased as a function of storage time, whereas $b^{*}$ values increased. These changes in color parameters showed yellower and a darker appearance at the end of the storage in comparison with the initial microcapsules (Table 5). Binsi et al. (2017) reported that the oxidation of triacylglycerols and free fatty acids can lead to changes in color, indicating the degree of deterioration of foods with high fat content. Thus, the color changes observed during storage would be associated with the oxidation of the surface oil of the microcapsules, which produced colored oxidation products.

\subsubsection{Particle size distribution and mean diameter of the reconstituted emulsions}

The mean diameter and droplet size distribution of reconstituted emulsions after freeze-drying were analyzed. The reconstitution of emulsions was made with distilled water ( $1 \mathrm{~g}$ solids/ $10 \mathrm{~g}$ emulsion) at $\sim 25^{\circ} \mathrm{C}$ for 30 min under stirring (Ixtaina et al., 2015).

Fig. 3 shows the particle size distribution curves of the reconstituted emulsions prepared with different wall protein:carbohydrate ratios and oil concentrations. All reconstituted emulsions showed a bimodal distribution, except the formulation 200C10L which presented three modes. It was observed that the influence of the heat treatment improved the homogeneity of the systems studied. The same effect of the heat treatment on the width of the distribution had been recorded for the parent emulsions, shown that the good emulsifying property of the protein-carbohydrate conjugates produced from MRP was not affected by the microencapsulation process. In all cases the particle size distribution of the reconstituted emulsions was considerably wider (Span values: 3.1785-31.7865) than those of the parent emulsions. Similar results were reported during the microencapsulation of chia seed oil by spray drying (Ixtaina et al., 2015; Rodea-González et al., 2012). The particle size increased with greater oil and lactose concentration and decreased with the application of heat treatment. This last case
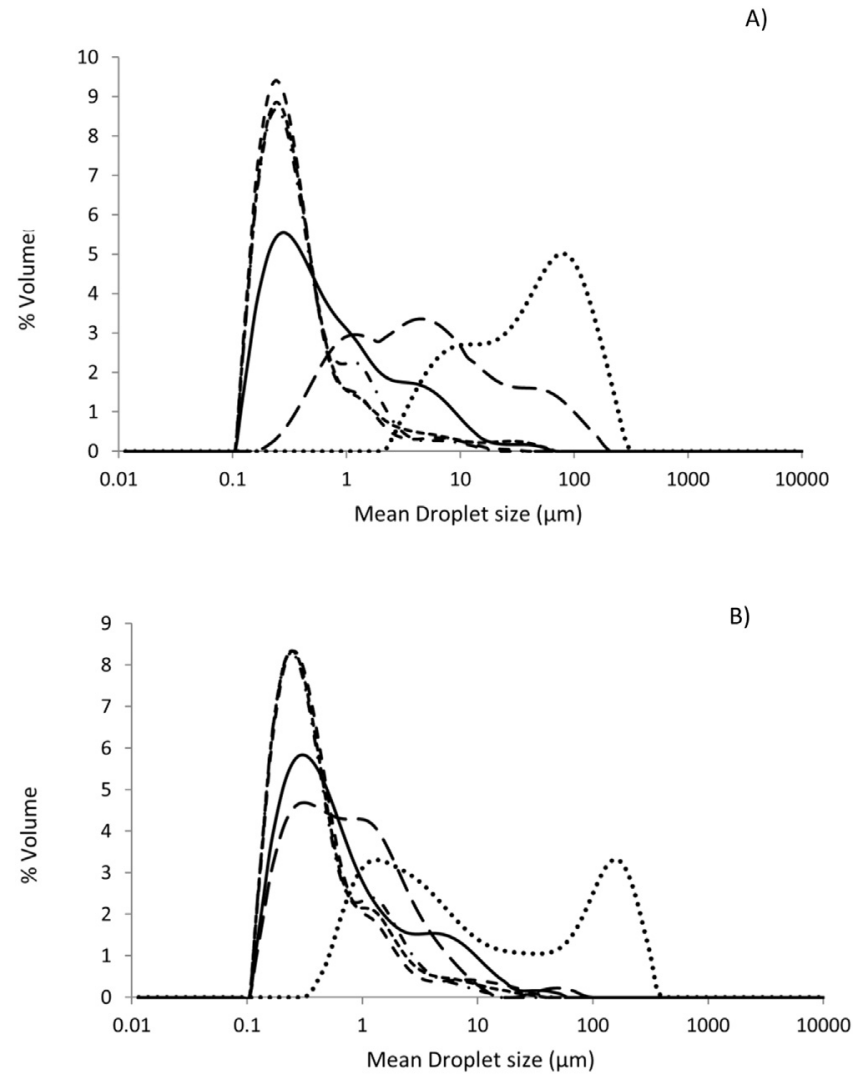

Fig. 3. Particle size distribution (\% volume) of reconstituted emulsions: A) without heat treatment B) with heat treatment - . - . 100C10L; - 150C10L; - 200C10L; - - - 100C20L; -..-. 150C20L; .......... 200C20L. 

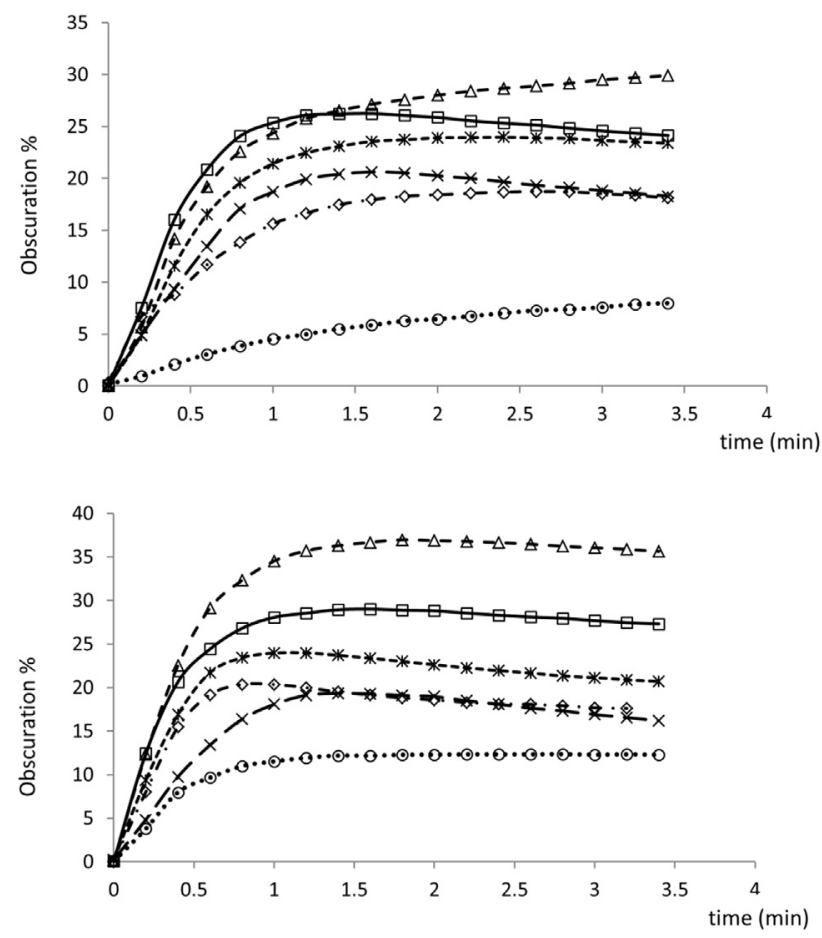

Fig. 4. Influence of stirring time on obscuration of chia seed oil microcapsules: A) without heat treatment B) with heat treatment- $\checkmark-100 \mathrm{C} 10 \mathrm{~L}$; $\square-150 \mathrm{C} 10 \mathrm{~L}$; - \pm - 200C10L; -X-100C20L; --*--150C20L; ...٪.. 200C20L.

can be explained by the better emulsification obtained, which delays the flocculation. The curves with the highest homogeneity were associated with $10-15 \%$ of oil (Fig. 3 A and B). The statistical analysis indicated that the droplet size $\mathrm{D}[3,2]$ presented interactions between the factors, being the most important interactions oil load $\mathrm{x}$ heat treatment $(\mathrm{p} \leq 0.001)$ and oil load $\mathrm{x}$ lactose concentration $(\mathrm{p} \leq 0.01)$ (Table 2$)$.

\subsubsection{Dispersibility}

One of the most important properties of microcapsules is related to the speed and efficiency of powder to disperse in water (Klinkesorn et al., 2005). Therefore, the laser diffraction technique was used to obtain information about this parameter. The dispersibility of powdered emulsions was measured recording the obscuration and mean particle diameter $\mathrm{D}[3,2]$ changes as a function of stirring time.

At the initial time of the storage $(t=0)$, the obscuration increased sharply with the agitation up to approximately $1 \mathrm{~min}$, and then remained constant after that time for most of the samples, except those with $20 \%$ of chia oil, $10 \%$ and $20 \%$ of lactose and not heat treated, which continued to grow slightly (Fig. 4 A). Samples with heat treatment (Fig. 4 B) showed a similar behavior. The highest obscuration values were related to samples with $20 \%$ of chia oil and $10 \%$ of lactose (with and without heat treatment), whereas those with $20 \%$ of chia oil and $20 \%$ of lactose recorded the lowest values.

Additionally, the D [3,2] decreased quickly until $0.2 \mathrm{~min}$, after which the particle size remained stable as a function of stirring time (Fig. 5).

The fast reduction in particle size and the increase in obscuration showed that most of the powder dissolved rapidly, giving a homogeneous suspension (Klinkesorn et al., 2005).

These parameters are important because they allow us to
A)
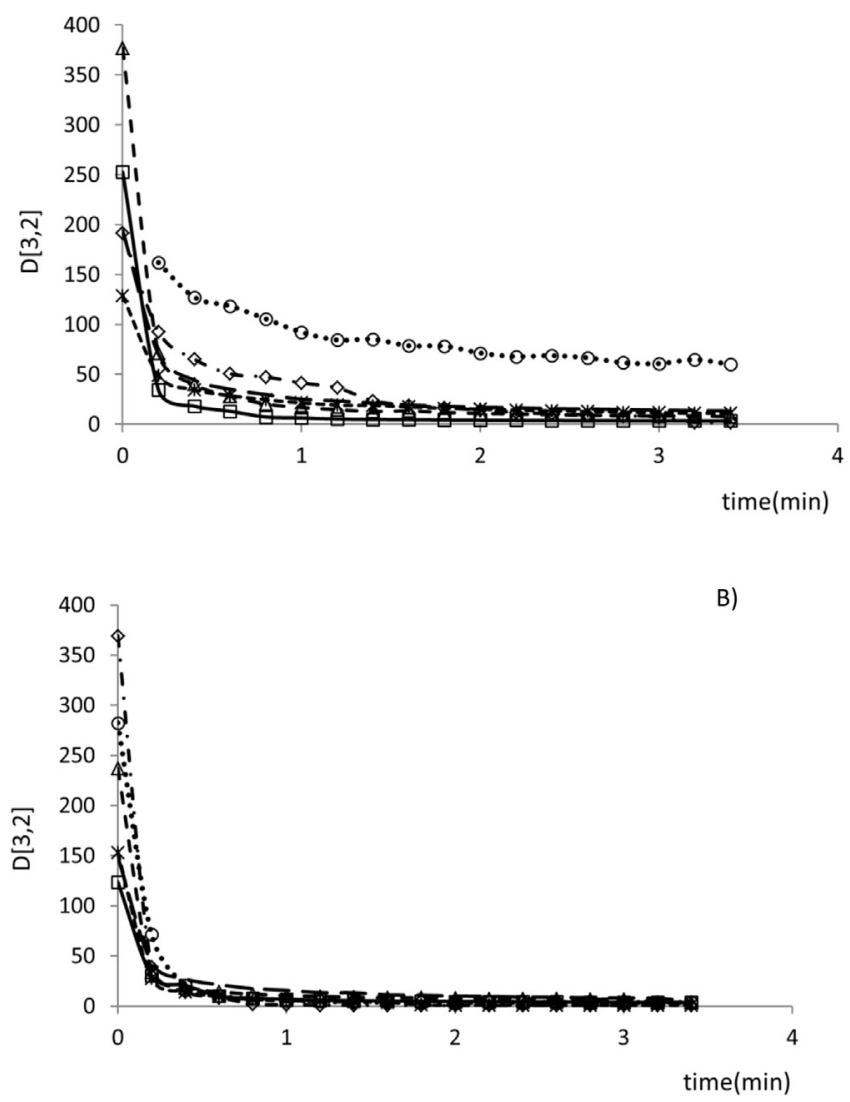

Fig. 5. Influence of stirring time on mean diameter of chia seed oil microcapsules: A) without heat treatment B) with heat treatment.- $-100 \mathrm{C} 10 \mathrm{~L}$; $\square$ 150c10L; - $4-200 \mathrm{C} 10 \mathrm{~L} ;--100 \mathrm{C} 20 \mathrm{~L} ;--*--150 \mathrm{C} 20 \mathrm{~L} ; \ldots \odot . . .200 \mathrm{C} 20 \mathrm{~L}$.

evaluate the rehydration of powder. In Fig. 5 it can be seen that the particle size significantly reduced in the first few seconds of stirring, which is very favorable for solubilization and subsequent application in instant foods.

\subsubsection{Oxidative stability}

The oxidative stability of microencapsulated chia oil was evaluated by Rancimat immediately after drying $(t=0 \mathrm{~d})$ and during storage $(t=30 \mathrm{~d})$. The oxidative stability of the chia oil was effectively enhanced by freeze-drying microencapsulation, since all systems presented higher induction times $\left(t_{i}\right)$ than those corresponding to bulk chia oil $\left(t_{i}=2.46 \pm 0.07 \mathrm{~h}\right)$. At $\mathrm{t}=0 \mathrm{~d}$, the highest induction time was found for the 100C20LHT sample (Table 3). At this time, the statistical analysis indicated that all factors affected the oxidative stability (Table 2). Also, double and triple interactions between factors were found, except lactose concentration $\mathrm{x}$ heat treatment. For samples with 10 and $15 \%$ of oil, the highest lactose concentration produced an increase of the induction time. In contrast, samples with $20 \%$ of oil showed an inverse behavior. The heat treatment showed a positive effect on the induction time for systems with $20 \%$ chia oil, $10 \%$ lactose and $10 \%$ chia oil and $20 \%$ lactose. This can be explained by the formation of protein-lactose conjugates which reduce the amount of hydroperoxides in the powders. It can also be seen that in samples containing 10 or $15 \%$ of oil, a 1:2 NaCas:lactose ratio improved the oxidative stability in comparison with those with 1:1ratio. Thus, the protein:carbohydrate ratio is an important factor in the Maillard reaction since a 
greater amount of reducing sugars available to participate in the reaction increases its rate and extent. These results suggest that the conjugates obtained by the Maillard reaction in the wall material are appropriated to improve the oxidative stability of microencapsulated chia seed oil. Similar results were obtained by Zhang et al. (2015) in the microencapsulation of fish oil using caseinate and maltodextrin. Research studies have shown that the Maillard reaction antioxidant products are formed as a result of the interaction of sugars with amino acids whether these products are at the interface or in the continuous matrix of the powder (Lingnert, Vallentin, \& Erikssonsik, 1979; McGookin \& Augustin, 1991). Because this reaction is very common in foods, especially those rich in heat-treated proteins, the heat treatment was applied in this study to promote antioxidant products that could protect the microencapsulated chia oil.

At the end of storage, the induction time decreased significantly for all the samples (data not shown). Only oil load $\times$ lactose interaction was found.

A similar trend was recorded for the influence of the heat treatment in terms of PV (data not shown). .

\section{Conclusion}

Microcapsules of chia oil were investigated in order to evaluate the influence of MRPs, oil concentration and protein:carbohydrate ratio in the wall on the physicochemical characteristic and stability of chia oil. The oil load, the lactose concentration and the heat treatment of the aqueous phase influenced the microencapsulation efficiency of total oil, $\omega-6$ and $\omega-3$ PUFAs, the oxidative stability of microcapsules and the particle size of the reconstituted emulsions. Moisture and water activity levels were low and suitable for dried products. The essential fatty acid composition of microencapsulated chia oil was similar to that of bulk oil, recording high levels of essential fatty acids, mainly $\omega-3$ PUFAs. All formulations exhibited good and fast dispersibility which is important in order to the rehydration properties of powders. The application of the heat treatment was beneficial for most of the variables studied, except for microencapsulation efficiency. The obtained results showed that the MRPs produced by heat treatment of NaCas-lactose mixture with different protein:carbohydrate ratios were effective for conferring microencapsulated chia oil additional oxidative stability.

\section{Conflict of interest}

The authors declare no conflict of interest.

\section{Acknowledgements}

The authors would like to thank the financial support given by Universidad Nacional de La Plata (UNLP) (11/X756), PIP 0713 CONICET, PICT 20130563 and Yulia B. Monakhova Spectral Service GmbH Laboratorium fur Auftragsanalytik, Germany for her technical assistance. Authors wish to thank Edelflex S.A. for its collaboration with the valve homogenizer.

\section{References}

Akhtar, M., \& Dickinson, E. (2007). Whey protein-maltodextrin conjugates as emulsifying agents: An alternative to gum Arabic. Food Hydrocolloids, 21, 607-616.

Augustin, M. A., Bhail, Cheng,L. J., Shen, Z., Oiseth, S., \& Sanguansri, L. (2015). Use of whole buttermilk for microencapsulation of omega-3 oils. Journal of Functional Foods, 19, 859-867.

Augustin, M. A., Sanguansri, L., \& Bode, O. (2006). Maillard reaction products as encapsulants for fish oil powders. Food Engineering and Physical Properties, 71, 25-32.
Ayerza, R., \& Coates, W. (2005). Chia: Rediscovering a forgotten crop of the aztecs. Tucson, Arizona: The Arizona Board of Regentsed.

Baik, M. Y., Suhendro, E. L., Nawar, W. W., McClements, D. J., Decker, E. A., \& Chinachoti, P. (2004). Effects of antioxidants and humidity on the oxidative stability of microencapsulated fish oil. Journal of American Oil Chemists Society, $81,355-360$.

Binsi, P. K., Nayak, N., Sarkar, P. C., Jeyakumari, A., Muhamed Ashraf, P., Ninan, G. et al. (2017). Structural and oxidative stabilization of spray dried fish oil microencapsulates with gum Arabic and sage polyphenols: Characterization and release kinetics. Food Chemistry, 219, 158-168.

Calvo, P., Hernández, T., Lozano, M., \& González-Gómez, D. (2010). Microencapsulation of extra-virgin olive oil by spray-drying: Influence of wall material and olive quality. European Journal of Lipid Science and Technology, 112, 852-858. http://dx.doi.org/10.1002/ejlt.201000059.

Chen, Q., Zhong, F., Wen, J., McGillivray, D., \& Quek, S. Y. (2013). Properties and stability of spray-dried and freeze-dried microcapsules co-encapsulated with fish oil, phytosterol esters, and limonene. Drying Technology, 31, 707-716. http://dx.doi.org/10.1080/07373937.2012.755541.

Choi, M. J., Briançon, S., Bazile, D., Royere, A., Min, S. G., \& Fessi, H. (2007). Effect of cryoprotectant and freeze-drying process on the stability of $\mathrm{W} / \mathrm{O} / \mathrm{W}$ emulsions. Drying Technology, 25, 809-819. http://dx.doi.org/10.1080/07373930701370183.

Diaz, M., Dunn, C. M., MCClements, D. J., \& Decker, E. A. (2003). Use of caseinophosphopeptides as natural antioxidants in oil-in-water emulsions. Journal of Agricultural and Food Chemistry, 51, 2365-2370.

Escalona-García, L. A., Pedroza-Islas, R., Natividad, R., Rodríguez-Huezo, M. E., Carrillo-Navas, H., \& Perez-Alonso, C. (2016). Oxidation kinetics and thermodynamic analysis of chia oil microencapsulated in a whey protein concentratepolysaccharide matrix. Journal of Food Engineering, 175, 93-103.

Fazaeli, M., Emam-Djomeh, Z., Kalbasi Ashtari, A., \& Omid, M. (2012). Effect of spray drying conditions and feed composition on the physical properties of black mulberry juice powder. Food and Bioproducts Processing, 90(4), 667-675.

Fitzpatrick, J. J. (2005). In C. Onwulata (Ed.), Food powder flowability in encapsulated and powdered foods (pp. 247-260). http://dx.doi.org/10.1201 9781420028300.ch10.

Gan, C. Y., Cheng, L. H., \& Easa, A. M. (2008). Evaluation of microbial transglutaminase and ribose cross-linked soy protein isolate-based microcapsules containing fish oil. Innovative Food Science and Emerging Technologies, 9, $563-569$.

Gharsallaoui, A., Roudaut, G., Chambin, O., Voilley, A., \& Saurel, R. (2007). Applications of spray-drying in microencapsulation of food ingredients: An overview. Food Research International, 40, 1107-1121.

González, A., Martínez, M. L., Paredes, A. J., León, A. E., \& Ribotta, P. D. (2016). Study of the preparation process and variation of wall components in chia (Salvia hispanica L.) oil microencapsulation. Powder Technology, 301, 868-875.

Goyal, A., Sharma, V., Sihag, M. K., Tomar, S. K., Arora, S., Sabikhi, L., et al. (2015) Development and physico-chemical characterization of microencapsulated flaxseed oil powder: A functional ingredient for omega-3 fortification. Powder Technology, 286, 527-537.

Hogan, S. A., McNamee, B. F., O'Riordan, E. D., \& O'Sullivan, M. (2001). Microencapsulating properties of sodium caseinate. Journal of Agricultural and Food Chemistry, 49, 1934-1938.

Holgado, F., Márquez-Ruiz, G., Dobarganes, C., \& Velasco, J. (2013). Influence of homogenization conditions and drying method on physicochemical properties of dehydrated emulsions containing different solid components. International Journal of Food Science and Technology, 48, 1498-1508.

Ixtaina, V. Y., Julio, L. M., Wagner, J. R., Nolasco, S. M., \& Tomás, M. C. (2015). Physicochemical characterization and stability of chia oil microencapsulated with sodium caseinate and lactose by spray-drying. Powder Technology, 271, 26-34. http://dx.doi.org/10.1016/j.powtec.2014.11.006.

Ixtaina, V. Y., Martínez, M. L., Spotorno, V., Mateo, C. M., Maestri, D. M., Diehl, B. W. K., et al. (2011). Characterization of chia seed oils obtained by pressing and solvent extraction. Journal of Food Composition and Analysis, 24, 166-174. http://dx.doi.org/10.1016/j.jfca.2010.08.006.

Ixtaina, V. Y., Nolasco, S. M., \& Tomás, M. C. (2012). Oxidative stability of chia (Salvia hispanica L.) seed oil: Effect of antioxidants and storage conditions. Journal of the American Oil Chemists' Society, 89, 1077-1090. http://dx.doi.org/10.1007/ s11746-011-1990-X.

Jacobsen, C., Sørensen, A.-D. M., \& Nielsen, N. S. (2013). Stabilization of omega-3 oils and enriched foods using antioxidants. In C. Jacobsen, N. S. Nielsen, A. F. Horn, \& A.-D. M. Sørensen (Eds.), Food enrichment with omega-3 fatty acids (pp. 130-146). http://dx.doi.org/10.1533/9780857098863.2.130 (Cambridge, UK).

Kaushik, P., Dowling, K., Barrow, C. J., \& Adhikari, B. (2015). Microencapsulation of omega-3 fatty acids: A review of microencapsulation and characterization methods. Journal of Functional Foods, 19, 868-881. http://dx.doi.org/10.1016/ j.jff.2014.06.029.

Klaypradit, W., \& Huang, Y.-W. (2008). Fish oil encapsulation with chitosan using ultrasonic atomizer. Lwt-food Science and Technology, 41, 1133-1139. http:// dx.doi.org/10.1016/j.lwt.2007.06.014.

Klinkesorn, U., Sophanodora, P., Chinachoti, P., McClements, D. J., \& Decker, E. A. (2005). Stability of Spray-dried tuna oil emulsions encapsulated with twolayered interfacial membranes. Journal Agricultural and Food Chemistry, 53, 8365-8371.

Lingnert, H., Vallentin, K., \& Erikssonsik, C. E. (1979). Measurement of antioxidative effect in model system. Journal of Food Processing and Preservation, 3, 87-103. Martínez, M. L., Curti, M. I., Roccia, P., Llabot, J. M., Penci, M. C., Bodoira, R. M., et al. 
(2015). Oxidative stability of walnut (Juglans regia L.) and chia (Salvia hispanica L.) oils microencapsulated by spray drying. Powder Technology, 270, 271-277. http://dx.doi.org/10.1016/j.powtec.2014.10.031.

McGookin, B. J., \& Augustin, M. A. (1991). Antioxidant activity of casein and Maillard reaction products from casein-sugar mixtures. Journal of Dairy Research, 58 $313-320$.

Onwulata, C. I., Konstance, R. P., \& Holsinger, V. H. (1996). Flow properties of encapsulated milkfat powders as affected by flow agent. Journal of Food Science, $61,1211-1215$.

O'Dwyer, S. P., O'Beirne, D., Eidhin, D. N., \& O'Kennedy, B. T. (2013). Effects of sodium caseinate concentration and storage conditions on the oxidative stability of oilin-water emulsions. Food Chemistry, 138, 1145-1152.

Quispe-Condori, S., Saldaña, M. D. A., \& Temelli, F. (2011). Microencapsulation of flax oil with zein using spray and freeze drying. LWT - Food Science and Technology, 44, 1880-1887.

Rodea-González, D. A., Cruz-Olivares, J., Román-Guerrero, A., RodríguezHuezo, M. E., Vernon-Carter, E. J., \& Pérez-Alonso, C. (2012). Spray-dried encapsulation of chia essential oil (Salvia hispanica L.) in whey protein concentrate-polysaccharide matrices. Journal of Food Engineering, 111, 102-109.

Rosenberg, M., \& Sheu, T.-Y. (1996). Microencapsulation of volatiles by spray-drying in whey protein-based wall systems. International Dairy Journal, 6, 273-284.

Rusli, J. K., Sanguansri, L., \& Augustin, M. A. (2006). Stabilization of oils by microencapsulation with heated protein-glucose syrup mixtures. Journal of the American Oil Chemists' Society, 83(11), 965-972.

Sanguansri, L., \& Augustin, M. A. (2007). Processing technologies in microencapsulation and delivery of omega-3 fatty acids. In J. Shi (Ed.), Functional food ingredients and Nutraceuticals: Processing technologies (pp. 297-327). http:// dx.doi.org/10.1201/9781420004076.

Velasco, J., Marmesat, S., Dobarganes, C., \& Márquez-Ruiz, G. (2006). Heterogeneous aspects of lipid oxidation in dried microencapsulated oils. Journal of Agricultural and Food Chemistry, 54, 1722-1729.

Zhang, Y., Tan, C., Abbas, S., Eric, K., Xia, S., \& Zhang, X. (2015). Modified SPI improves the emulsion properties and oxidative stability of fish oil microcapsules. Food Hydrocolloids, 51, 108-117. 